infants. During both study periods inulin clearance wats proportional to gestational age. The slopes of the regression lines for $C_{\text {in }}$ vs. gestational age were significantly different. The absolute increases in $C_{i n}$ following 2-3 days of extrauterine adaptation were greater for the near term infants than for the markedly preterm ones.

\section{REFEREN(ISS AND NOTHS}

1. Alexander. D. P... and Nixon. D. A.: Plasma clearance of P-amino-hippuric acid by the kidneys of fetal. neonatal and adult sheep. Nature, 194: 483 (1962).

2. Cole, B. R. Giangiacomo, J., Ingelfinger, J., and Robson. A .: Measurement of renal function without urine collection. N. Engl. J. Med., 287: 1109 (1972)

3. Dauber, I. M.. Krauss, A. N.. Symchych, P. S.. and Auld, P. A. M.: Renal failure following perinatal anoxia. J. Pediat., 88: 851 (1476)

4. Dubawitz L. M. Dubowitz. U. and Goldbery. (. . Clinical assessment of gestational age in the newhorn infant. J. Pediat. 77: 1 (1970).

5. Guignard. J. P.. Torrade. A.. Dat Cunha, ().. and Gatutier, E.: Glomerulat filtration rate in the first three weeks of life. J. Pediat.. 87: 268 (1975).

6. Guignard. J. P.. Torrado, A.. Mazouni. S. M., and Gauticr. F.: Renal function in respiratory distress syndrome. J. Pediat., 88: 845 (1976).

7. Kagan. B. M. Stanincoval, V.. Felix, N. S., Hodgman, J.. and Katman. D Body composition of premature infants: Relation to nutrition. Amer. J Clin. Nutr. 25:115.3(1972).

x. Leake, R. D. Trygstad. (. W... and ()$h$. W .: Inulin clearance in the newhorn infant: Relationship to gestational and postnatal age. Pediat. Res.. 10: 759 (1976).

9. Lake, R. D. Zakauddin, S. Trygstad. ( . W., Fu, P.. and ()h. W.: The effects of large volume intravenous fluid infusion on neonatal renal function. J. Pediat. 89: 968 (1976).

10. ()h, W.. Oh, M. A., and lind. J.: Renal function and blood volume in newhorn infants related to placental transfusion. Actat Patediat. Scand. 56 $197(1966)$

11. Robillard. J. E... Kulvinskas, (C.. Sessions, ( .. Burmeister, 1... and Smith. I (i.: Maturational changes in the fetal glomerular filtration rate. Amer. J. Obstet. Ciynecol.. 122: 601) (1975).

12. Roc J. H. Fpstein, J. H. and Coldstein. N. P.: A photometric methed for the determination of inulin in plasma and urine. J. Biol. Chem., 178: 8.39 (1949).

13. Requests for reprints should be addressed to: R. D. Lecake. M.D. Department of Pediatrics, Harbor (ieneral Hospital, $1000 \mathrm{~W}$. Carson St.. Torrance, (alif. 90509 (USA).

14. Received for publication July 19. 1976

15. Accepted for publication February 15, 1977
Energy homeostasis glucagon

glucose insulin

neonate somatostatin

\title{
Effects of Somatostatin (SRIF) Infusion on Glucose Homeostasis in Newborn Lambs: Evidence for a Significant Role of Glucagon
}

\author{
MARK A. SPERLING, ${ }^{\prime 3}$ I.UIZ (iRAJWER, ROSEMARY D. L.EAKE, AND DEIBERT A. FISHER \\ Department of Pediatrics, UCLA-Harbor General Hospital, Torrance. California, USA
}

\section{Summary}

In order to investigate the significance and relative contribution of glucagon (IRG) and insulin (IRI) to neonatal glucose homeostasis, studies were conducted utilizing somatostatin (SRIF) in newborn fasting lambs aged 1-3 days. A priming dose followed by constant infusion of SRIF was maintained for $2 \mathrm{hr}$. During the first hour, SRIF alone was infused (period $A$ ); during the second hour, glucagon or insulin were additionally infused (period $B)$; recovery was assessed $30 \mathrm{~min}$ after cessation of infusions (period $C$ ). During period $A$, a rapid and sustained suppression in the plasma concentrations of IRG and IRI occurred $(P<0.01)$, accompanied by a fall in plasma glucose significant at $60 \mathrm{~min}$. Reinfusion of glucagon $(5 \mathrm{ng} / \mathrm{kg} / \mathrm{min})$ during period $B$ raised IRG by $342 \pm 92 \mathrm{pg} / \mathrm{ml}$ (mean $\pm S E M, P$ $<0.01$ ). Despite ongoing SRIF, plasma IRI also rose by $19.7 \pm$ $7 \mu \mathrm{U} / \mathrm{ml}(P<0.05)$ and was not accountable by contamination of the infused glucagon with insulin. Plasma glucose rose modestly, perhaps as a result of the antagonistic effects of glucagon and insulin. After cessation of SRIF and glucagon infusions (period C) plasma IRG fell, plasma IRI rose, and plasma glucose fell significantly $(16.5 \pm 4 \mathrm{mg} / \mathrm{dl}, P<0.01)$. When insulin $(0.1$ units/kg/hr) was infused in period $B$, plasma IRI rose to approximately $70 \mu \mathrm{U} / \mathrm{ml}$, plasma IRG remained suppressed and plasma glucose fell profoundly, recovering during period $C$ as plasma IRI fell and plasma IRG rose. When, during period $B$, glucagon was infused at 10 times the original dose, plasma glucose concentration doubled despite a plasma IRI concentration of 100 $\mu \mathrm{U} / \mathbf{m l}$.

These results demonstrate that: (1) SRIF effectively inhibits IRI and IRG secretion in newborn lambs; (2) glucose falls when both hormones are acutely suppressed, suggesting that glucagon is a major hormone for maintaining blood glucose concentration during short term fasting; a rise in glucose, as occurs in insulindeficient diabetes, would be expected if insulin were the dominant hormone; (3) both insulin and glucagon and acute changes in the effective ratio of these hormones modulate glucose homeostasis; and (4) at physiologic concentrations glucagon can overcome the suppressive effects of SRIF on insulin secretion in newborn lambs.

\section{Speculation}

In the lamb, insulin and glucagon are both important for neonatal glucose homeostasis. Acute changes in the ratio of these two hormones can effectively modulate plasma glucose concentration presumably through governing hepatic glucose output and/or peripheral glucose utilization. Extrapolation, 
made with due caution to human newborns, would suggest that the observed changes in glucagon and insulin in the immediate postnatal period have physiological significance in glucose homeostasis.

In the mature organism, glueose homeostasis is modulated by insulin and glucagon and by the effective interaction of these two pancreatic hormones $(1,22,24,30)$. However, the relative contribution of these hormones to glucose homeostasis in the newborn has not been determined. It is known that plasma immunoreactive glucagon concentration (IRG) increases promptly following delivery in a number of species $(2,16,17$. 28) and rises again between the first and third days of life in the human neonate, whereas plasma insulin concentration (IRI) remains low throughout $(16,17,28)$. In the adult the effect of this hormonal pattern (high glucagon, low insulin) on liver metabolism would be to promote glycogenolysis (4), gluconeogenesis (8). and ketogenesis (21). In order to determine whether this pattern of high glucagon and low insulin concentration is of significance in modulating neonatal glucose metabolism, we employed SRIF, a hypothalamic peptide known to inhibit the secretion of several hormones, including IRG and IRI $(6,7,11-15$. $19,20,31,32)$. Studies were conducted in the newborn lamb during SRIF infusion with and without infusion of either insulin or glucagon at physiologic concentrations to determine the selective contribution of each hormone.

\section{MATERIALS AND MITHOIDS}

\section{ANIMAIS AND IXPPERIMINTS}

Newborn lambs delivered spontaneously at term (circa 150 days) to healthy (olumbia-Suffolk ewes were studied 24-72 hr after birth. Under local anesthesia catheters were implanted into a carotid artery for blood sampling and into the jugular vein for infusion of test substances. After recovery from surgery and after at least $4 \mathrm{hr}$ of fasting the following experiments were performed.

In a series of experiments. cyclic SRIF (a gift from Dr. Roger Guillemin) was infused as a bolus of $50 \mu \mathrm{g}$ (in $0.5 \mathrm{ml}$ saline) followed by constant infusion at a dose of $200 \mu \mathrm{g} / \mathrm{hr}$ for $120 \mathrm{~min}$.
The stock solution was made up immediately prior to use by dissolving $500 \mu \mathrm{g}$ of SRIF in $5 \mathrm{ml}$ isotonic saline solution: $0.5 \mathrm{ml}$ was set aside for the bolus and the remainder was added to $50 \mathrm{ml}$ saline and infused via a constant infusion pump (Harvard). During the first (period $A$ ) SRIF only was infused: during the second hour (period B) glucagon (Eli Lilly, $1 \mathrm{mg} / \mathrm{ml}$ ) diluted in saline was added to the infusate at a dose of $5 \mathrm{ng} / \mathrm{kg} / \mathrm{min}$. Eight animals were studied in this manner.

In three other animals, an identical protocol was followed except that insulin rather than glueagon was added to the infusate during the second hour (period $B$ ) at a dose of 0.1 units $/ \mathrm{kg} /$ hr.

In one final experiment during the second hour (period $B$ ), glucagon wals added at $50 \mathrm{ng} / \mathrm{kg} / \mathrm{min}, i . c^{\prime} .10$ times the dose employed in carlier experiments.

The weight of these animals was $3400 \pm 205 \mathrm{~g}$ (mean \pm SEM). In each experiment sequential blood samples were withdrawn before and during infusion of the test substance at the times indicated in the tables and graphs. These times were chosen so as to permit examination of the rapid $(5 \mathrm{~min})$ and more prolonged $(60 \mathrm{~min})$ responses resulting from the infusion of SRIF only (period $A$ ), the effect during reinfusion of glucagon or insulin $(60-120 \mathrm{~min}$; period $B)$ and the effects 30 min after ceasing all infusion (period (c).

\section{ANAIYTIC TIE(HNIOUI:S}

Each blood sample of $2 \mathrm{ml}$ was placed into chilled tubes containing ethylenediamine tetratacetic acid (I:DTA) and 1000 Kallikrein inhibitory units of aprotinin (Trasylol), an inhibitor of glucagon degradation. The plasma was separated promptly in a refrigerated eentrifuge and stored frozen at $-20^{\circ}$ until assayed. Fach sample was analyzed for glucose by a glucose oxidatse technique (Beckman glueose analyzer. Beckman Instruments. Fullerton. (alif.), glucagon by radiommunoassaty using antiserum (il-5 and |2:1] glucagon, as previously described (27), and insulin by a double antibody radioimmunoassay (2.3) using a heterologous system of porcine insulin for labeling and standards. and a porcine insulin antiserum. Ovine insulin produces good displatement in this assay. The statistical analysis enployed Student'stetest and. where appropriate, the paired $t$-test

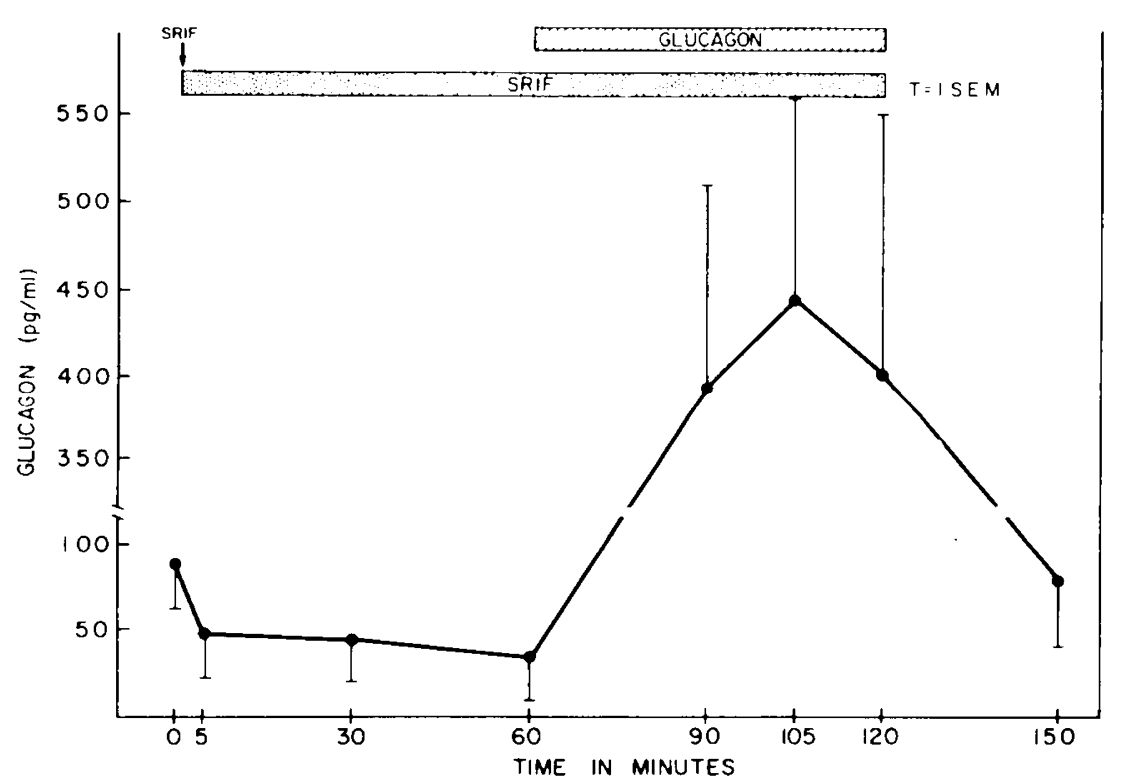

Fig. 1. The effect of infusing somatostatin (SRIF) with and without glucagon on plasma glucagon concentration in fasting newborn lambs. The SRIF was infused as a pulse (arrow) of $50 \mu \mathrm{g}$ followed by $200 \mu \mathrm{g} / \mathrm{hr}$. The glucagon was infused at $5 \mathrm{ng} / \mathrm{kg} / \mathrm{min}$. The changes induced hy the SRIF alone, reinfusion of glucagon, and cessation of infusion at $120 \mathrm{~min}$ are all significant. 


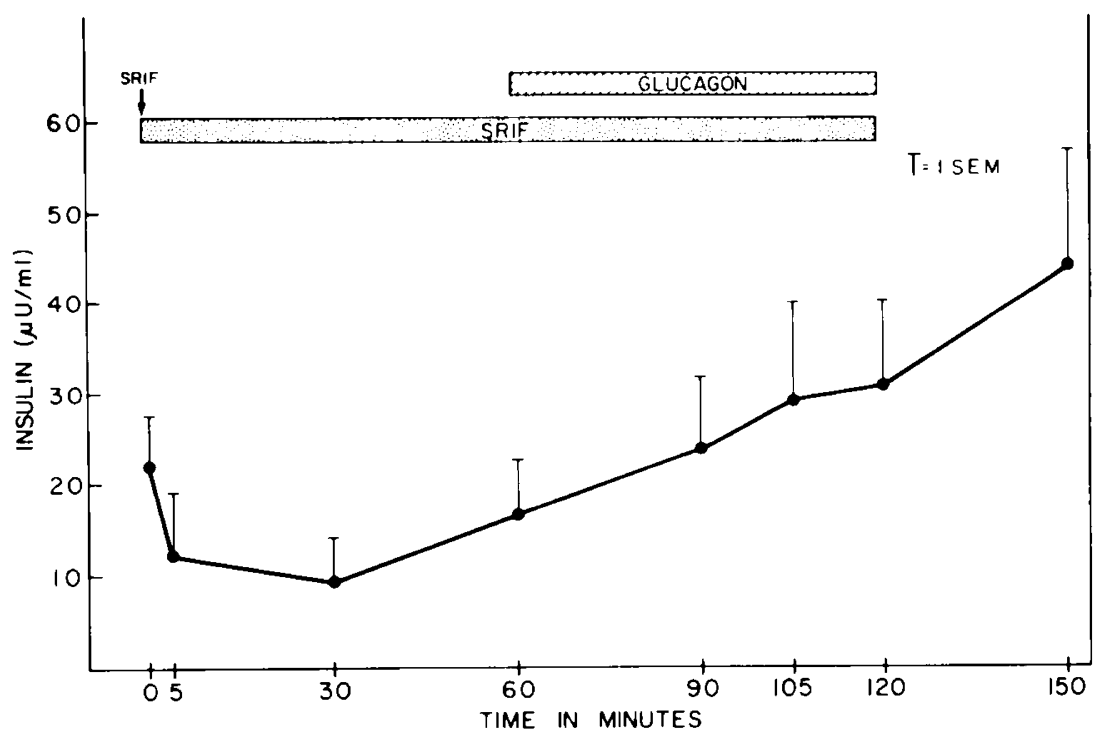

Fig. 2. The effect of infusing somatostatin (SRIF) with and without glucagon on plasma insulin concentration in fasting newborn lambs. Dose schedules employed were as described for Figure 1. Insulin was significantly suppressed by the SRIF alone. Insulin concentrations rise during glucagon infusion despite ongoing SRIF.

Table 1. Changes during somatostatin and glucagon infusion in newborn lambs

\begin{tabular}{|c|c|c|c|c|c|c|}
\hline & & & & & & \\
\hline & $(0)-5$ & $0-30$ & $0-60$ & $60-90$ & $60-120$ & $120-150$ \\
\hline $\begin{array}{l}\text { JGluciagon. } \mathrm{pg} / \mathrm{ml} \\
\pm \text { SI:M } \\
\text { No. animals }\end{array}$ & $\begin{array}{c}-43 \\
8 \\
(7) \\
\vdots\end{array}$ & $\begin{array}{r}-46 \\
9 \\
(7) \\
2\end{array}$ & $\begin{array}{c}-52 \\
8 \\
(6) \\
2\end{array}$ & $\begin{array}{l}3+2 \\
92 \\
(7) \\
:\end{array}$ & $\begin{array}{c}292 \\
123 \\
(7) \\
3\end{array}$ & $\begin{array}{c}-105 \\
40 \\
(7) \\
3\end{array}$ \\
\hline $\begin{array}{l}\text { JInsulin. } \mu \mathrm{U} / \mathrm{ml} \\
\pm \text { SI:M } \\
\text { No. animils }\end{array}$ & $\begin{array}{c}-4.0 \\
2 \\
(x) \\
2\end{array}$ & $\begin{array}{c}-11.2 \\
2 \\
(x) \\
2\end{array}$ & $\begin{array}{c}-7.8 \\
3 \\
(7) \\
3\end{array}$ & $\begin{array}{l}6.8 \\
4 \\
(8) \\
3\end{array}$ & $\begin{array}{l}19.7 \\
7 \\
(7)\end{array}$ & $\begin{array}{c}11.2 \\
7 \\
(8)\end{array}$ \\
\hline $\begin{array}{l}\text { د(ilucose, mg/loo } \mathrm{ml} \\
\pm \text { SEM } \\
\text { No. animals }\end{array}$ & $\begin{array}{r}-6.3 \\
3.4 \\
(7)\end{array}$ & $\begin{array}{c}-3.3 \\
7.6 \\
(7)\end{array}$ & $\begin{array}{r}-9.0 \\
3.5 \\
(6)^{3}\end{array}$ & $\begin{array}{l}10.4 \\
6.3 \\
(7)\end{array}$ & $\begin{array}{l}13.0 \\
9.6 \\
(7)\end{array}$ & $\begin{array}{c}-16.5 \\
4.25 \\
(6)^{2}\end{array}$ \\
\hline
\end{tabular}

1 The data are the same an those described in the text and in Figures 1 and 2. calculated by the paired, $t$-test for the sum of changes in each animal at each time point. (1-60): period $\mathrm{A}$; infusion of somatestatin only. 60-120): period $\mathrm{B}$ : infusion of somatostatin plus glucagon (5 $\mathrm{ng} / \mathrm{kg} / \mathrm{min})$. $120-150$ : period ( : recovery after ceasing all infusion at $120 \mathrm{~min}$.

$=P<0.01$.

${ }^{3} P<0.05$.

\section{RISUITS}

The effects of SRIF infusion alone on IRG are shown in Figure 1. The bolus induced a rapid fall in plasma IRG $i$ from 87 $\pm 25 \mathrm{pg} / \mathrm{ml}$ (mean $\pm \mathrm{SEM}$ ) to $48 \pm 26 \mathrm{pg} / \mathrm{ml}$ at $5 \mathrm{~min}:$ IRC; reached a nadir of $35 \pm 26 \mathrm{pg} / \mathrm{ml}$ at $60 \mathrm{~min}$. Reinfusion of glucagon raised plasma IR( $;$ concentrations to $39.3 \pm 122 \mathrm{pg} / \mathrm{ml}$ : mean levels remained at approximately $4(1) \mathrm{pg} / \mathrm{ml}$ throughout the period of glucagon infusion and fell to $77 \pm 3.5 \mathrm{pg} / \mathrm{ml}$ at 1.50 min. i.e., $30 \mathrm{~min}$ after cessation of the infusion.

Similarly (Figure 2), the mean basial insulin concentration of $21.3 \pm 6.4 \mu \mathrm{U} / \mathrm{ml}$ was rapidly suppressed by the bolus of SRIF to a value of $12.2 \pm 6.9 \mu \mathrm{U} / \mathrm{ml}$ at $5 \mathrm{~min}$; insulin reached a nadir of $9.6 \pm 4.4 \mu \mathrm{U} / \mathrm{ml}$ at $30 \mathrm{~min}$. whereas the value at 60 min was $16.6 \pm 5.9 \mu \mathrm{U} / \mathrm{ml}$. Reinfusion of glucagon during the second hour raised insulin values to a peak of $30.5 \pm 8.9 \mu \mathrm{U} / \mathrm{ml}$. In order to determine whether contamination of the infused glucagon with insulin could account for this rise in plasma IRI. I $\mu \mathrm{g}$ glucagon was measured and found to be equivalent to $2000 \mathrm{U}$ IRI in our radioimmunoassay system. Thus, since approximately $1 \mu \mathrm{g}$ glucagon (200 $\mu \mathrm{U}$ IRI) was infused over a $\mathrm{l}$-hr period $(5$ $\mathrm{ng} / \mathrm{kg} / \mathrm{min})$ into a $350(0) \mathrm{g}$ lamb, with a plasma volume of approximately $200 \mathrm{ml}$, only a $\mathrm{l}-\mu \mathrm{U} / \mathrm{ml}$ change in IRI can be attributed to the glucagon infused. whereas the observed changes were considerably greater. Moreover. when all infusions ceased. IRI rose still further to $4.3 .2 \pm 12.4 \mu \mathrm{U} / \mathrm{ml}$ at $150 \mathrm{~min}$.

Basal plasma glucose was $74.2 \pm 10.5 \mathrm{mg} / \mathrm{dl}$, and although values fell during SRIF infusion and rose during glucagon infusion. the changes were not significant when analyzed by Student's t-test. However, when the changes in IRG. IRI, and glucose at each time for the individual animals were analyzed by the paired $t$-test. significant changes were evident as demonstrated in Table 1 . During period A (SRIF alone), plasma IRG and plasma IRI fell significantly by $5 \mathrm{~min}$, and remained significantly suppressed throughout this period of only SRIF infusion (0-60 min). The extent of the mean fall from basal was similar 
for IRG and IRI (approximately $50 \mathrm{c}$ ). Glucose also fell, the change at 60 min being significant. Reinfusion of glucagon during period $B(60-120 \mathrm{~min})$ caused significant elevations in IRG and IRI as well as some rise in glucose, arresting the previous pattern of decline. Finally, the cessation of glucagon and SRIF infusion $(120-1.50 \mathrm{~min})$ was associated during period $\mathrm{C}$ with a significant fall in IRG, a rebound rise in IRI, and again a significant fall in glucose. Thus, suppression of both IRG and IRI resulted in a significant fall in glucose and reinfusion of glucagon reversed this fall in glucose. whereas the rise in IRI and fall in IRG, after discontinuing SRIF and glucagon infusion, again resulted in a significant fall in glucose.

When insulin was infused during period $B$. plasma IRI increased to peak concentrations of approximately $60-70 \mu \mathrm{U} / \mathrm{ml}$. whereas IRG remained undetectable. These results are shown in Figure 3. Only mean values are shown; standard errors of the mean are omitted because of the small number of experiments. Actual values for IRG were $55 \pm 28 \mathrm{pg} / \mathrm{ml}$ at zero time, falling to $1.5 \pm 8 \mathrm{pg} / \mathrm{ml}$ at $5 \mathrm{~min}$ : thereafter IRG was undetectable until all infusion stopped when IRG rose to $20 \pm 10 \mathrm{pg} / \mathrm{ml}$. Plasma IRI was $1.3 \pm 5 \mu \mathrm{U} / \mathrm{ml}$ at zero time and fell promptly to a nadir of $8 \pm 1 \mu \mathrm{U} / \mathrm{ml}$ at $60 \mathrm{~min}$. Reinfusion of insulin resulted in sustained clevations with a peak of $68 \pm 17 \mu \mathrm{U} / \mathrm{ml}$ at $120 \mathrm{~min}$. When infusion ceased IRI returned to $10 \pm 3 \mu \mathrm{U} / \mathrm{ml}$. Plasma glucose fell progressively from the basal value of $70 \pm 25 \mathrm{mg} / \mathrm{dl}$ to a sustained nadir of circa $20 \mathrm{mg} / \mathrm{dl}$ ( range $17 \pm 2 \mathrm{mg} / \mathrm{dl}$ to 24 $\pm 19 \mathrm{mg} / \mathrm{dl}$ ) throughout the period of insulin infusion. When infusion ceased. glucose recovered to $30 \mathrm{mg} / \mathrm{dl}$ coincident with the fall in IRI and rise in IRG.

In the final experiment in which glucagon $50 \mathrm{ng} / \mathrm{kg} / \mathrm{min}$ was infused during period $B$ (the second hour of SRIF infusion) plasma IRG rose to a peak of $4500 \mathrm{pg} / \mathrm{ml}$. a level lo-fold that achieved in the experiments when only $5 \mathrm{ng} / \mathrm{kg} / \mathrm{min}$ was infused. These results are shown in Figure 4 . Despite simultaneous SRIF infusion, plasma IRI rose to a peak of $100 \mu \mathrm{U} / \mathrm{ml}$, a valuc again unaccountable on the basis of contamination of the glucagon used. This peak value of IRI is not too dissimilar to that achieved in the animals into which insulin was infused (Figure 3). However, in contrast to the results depicted in Figure. 3 where IRI was high, plasma IRC; was low and plasma glucose fell profoundly, Figure + demonstrates that despite the similarly high plasma IRI, plasma glucose doubled when plasma IRG was markedly elevated.

\section{DISCUSSION}

SRIF has proved to be a useful probe with which to explore the effects of deficiency of both insulin and glucagon, or the selective deficiency of one by reinfusing the other hormone $(6$. 7. $11-15,19.20,31,32)$. No datat are available. however, regarding the effects of $S R I F$ in the neonatal period. The present studies provide these data in the newborn lamb. Flsewhere. We have reported that the acute rise in IRG which occurs shortly after delivery in humans and rats $(2,16,28)$ also oecurs in the newborn lamb (17). Moreover, the lamb in utere and in the neonatal period. unlike its adult counterpart. is not at ruminant. and consequently more suitable for studies of glucose homeostatsis $(5,10,18,29)$. The differences between the newborn and weaned sheep with regard to energy substrate may explain the reported lack of effect of SRIF in suppressing hasal plasma concentrations of IRG and IRI in adult sheep (.3), whereats in our newborn studies SRIF was clearly capable of acutely suppressing plasma IRG and IRI concentration.

The results of our experiments also provide evidence for a significant role of insulin and glucigon in modulating glucose homeostasis in the immediate neonatal period. Moreover, as in the mature organism, glucagon appears to be a major hormone for maintaining glucose homeostasis during short term fasting ( 1 . 6. 12, 14. 20. 32). Thus, during SRIF" infusion. When both plasma IRI and plasma IR(i levels were suppressed (Table 1). plasma glucose fell. If insulin were the dominant hormone, the deficiency of insulin should result in hyperglyeemiat. as occurs in diabetes mellitus. In diabetes. however. the insulin deficiency oceurs in the presence of relative glucagon excess $(6,7,11,12$. 14). Therefore, we attempted to simulate the hormonal situation existing in diabetes by reinfusing glucigon at a dose designed to clevale concentrations within the physiologic range. While maintaining low insulin through ongoing infusion of SRIF. The concentrations of IRG achieved were, in fact. Within the range existing in portal plasma (26). However. the rise in glucose during concomitant infusion of SRIF and glucagon wals modest and not significant. although the fall in plasma glucose was clearly reversed. It is reasonable to assume that the failure of glucatgon to cause at rise in glucose was due to the associated stimulation of insulin release with resultant modification of each hormone's effect. Since contamination by insulin of the glucagon used for infusion was excluded as the cause of the rise in plasma

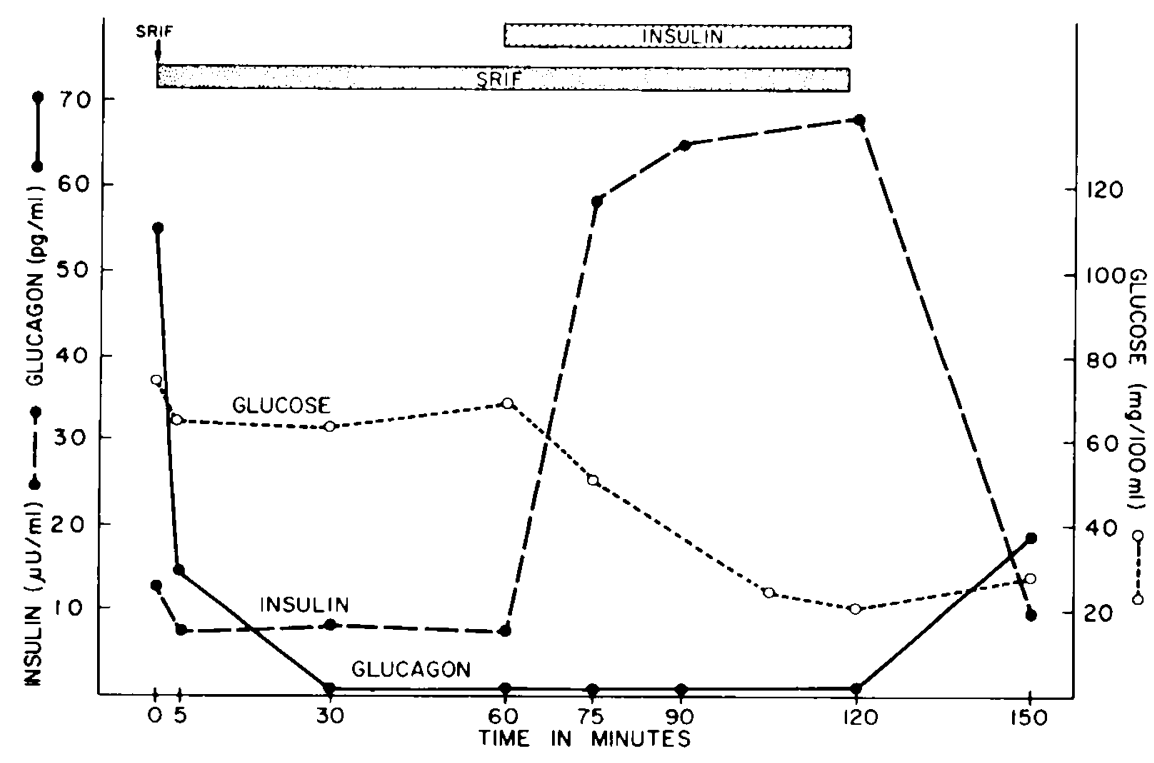

Fig. 3. The effect of infusing somatostatin (SRIF), with and without insulin. $0.1 \mathrm{U} / \mathrm{kg} / \mathrm{hr}$. on plasma concentration of insulin, glucagon, and glucose in fasting newborn lambs. Note the early fall in plasma glucose level when both insulin and glucagon also fall. Profound hypoglycemia results from physiologic insulin levels when glueagon is low, whereas partial recovery in glucose occurs as the hormone levels return toward normal. 


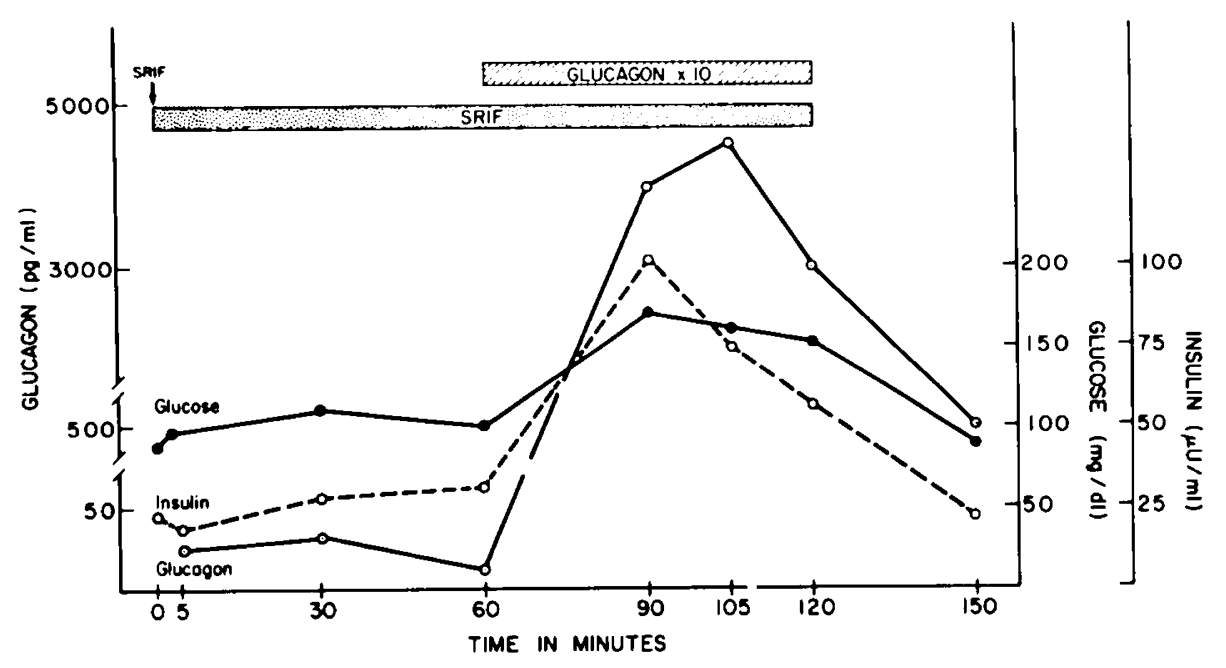

Fig. 4. The effect of infusing somatostatin (SR/F) with and without glucagon $50 \mathrm{ng} / \mathrm{kg} / \mathrm{min}$ on plasmat concentrations of glucagon. insulin, and glucose in fasting newborn lambs. Note that the glucose level rises when the glucagon level is high despite an insulin level of 100 () $\mu$ U/ml. (Compare with Figure 3.)

IRI. the glucagon must have been acting as a direct stimulant to insulin secretion despite ongoing SRIF infusion. Although the insulinotropic effect of glucagon is known (25). glucagon has not previously been described as overeoming the suppressive effect of SRIF on insulin secretion (13). Moreover. We used a dose of SRIF which, on a weight basis. was at least 5 -fold greater than doses employed in adult animals or man $(6,7,12-15,20,32)$. Thus, for reasons not defined. the newhorn lamb appears to respond differently than mature animals. One possible explanation is more rapid metabolic inactivation of SRIF in the newborn animal.

The effect of changes in the plasma concentrations of IRG and IRI on plasma glucose concentrations is also evident in our experiments. For example. the eessation of glucagon and SRIF infusion at $2 \mathrm{hr}$ resulted in a rapid fall in plasma IRG with a rebound rise in plasma IRI level evident 30 min later (Figs. 1 and 2). These hormonal changes during period ('were associated with a significant fall in plasma glucose concentration (Table 1). Similarly, the infusion of insulin during ongoing SRIF administration resulted in markedly suppressed plasma IRG levels and was associated with profound hypoglycemia (Fig. 3). However. a similar concentration of plasma IRI achieved at a time when plasma IR $;$ was markedly elevated during infusion of high dose glucagon in period $B$ was associated with a doubling of plasma glucose (Fig. 4). In this later experiment the stimulatory effect of glucagon on insulin secretion despite ongoing SRIF was again evident. The fact that the plasma concentration of IRG was, as expected, 10-fold higher than in animals infused with low dose glucagon emphasizes that it is the relative ratio of the two hormones that is involved in acutely modulating glucose homeostasis rather than absolute concentrations of either. It is not intended to imply that this ratio has some mathematical meaning, or that the relative ratio of circulating insulin and glucagon is the only determinant of long term glucose homeostasis. Indeed. recently reported studies suggest that glucagon has but a transient effect on hepatic glucose release, and that insulin may be predominant in long term glucose homeostasis $(9,26,32)$. Moreover, infusion of SRIF for a period of several hours results in an initial fall in the plasma concentrations of glucose. IRI and IRG followed after several hours by a rise in hepatic glueose output and a rise in peripheral blood glucose despite suppressed plasma IRG and IRI (9). Furthermore, SRIF may reduce splanchnic blood flow. so that some of the fall in plasma glucose during SRIF infusion may occur independently of the suppressive effects on IRI and IRG secretion (32), although this is disputed (6). Nevertheless, from the acute perturbations introduced in the short term experiments reported here, it is evident that at physiologic concentrations hoth insulin and glucagon are important in modulating glucose homeostasis in the neonatal period. These findings are in agreement with and amplify recently reported studies in mature man (9), and dog (6), which similarly demonstrate the rapid fall in glucose concentration when both IRG and IRI are acutely suppressed by SRIF and which estimate that basal glucagon is responsible for at least onethird of basal glucose production (6). Moreover, they strongly suggest that somatostatin has no acute effects on glucose turnover other than those induced through the changes in pancreatic hormone secretion (6). And finally, the studies demonstrate that high glucagon concentrations, in the absence of similar elevations in insulin. transiently increase hepatic glucose production, resulting in more sustained elevation of peripheral blood glucose concentrations (6. 7.9). Since plasma IRG rises abruptly whereas IRI remains low following delivery in a number of mammatian species, including the human $(2,16,17,28)$, and since acute changes in these hormones can modulate glucose homeostasis in the newborn period, as demonstrated in the present experiments, we suggest that the spontaneous changes in IRG and IRI following delivery may be important for maintaining glucose homeostasis during the critical adaptations following birth.

\section{CONCIUSION}

Studies were conducted in fasting lambs aged $1-3$ days in order to ascertain the sienificance of glucagon (IRG) and insulin (IRI) in neonatal glucose homeostasis. Infusion of somatostatin (SRIF), an inhibitor of pancreatic hormone secretion, suppressed plasma IRG and IRI levels, resulting in a fall in plasma glucose. Reinfusion of glucagon at physiologic or pharmacologic doses restored and elevated glucose, respectively, despite a concomitant rise of plasma IRI. Reinfusion of insulin while IRG was suppressed resulted in profound hypoglycemia. Thus, hoth hormones, and especially their effective interaction, appear to modulate blood glucose in the newborn. In short term fasting, glucagon appears to be the dominant hormone since, despite a simultaneous fall in insulin resembling the insulin concentrations in diabetes, glucose falls.

\section{REFHREN( FS AND NOTES}

1. Alford, F. P.. Bloom, S. R., Nabarro, J. D. N., Hall, R., Besser. G. M. . Cony. D. H., Kastin, A. H., and Schally, A. V.: Glucagon control of fasting glucose in man. Lancet, ii: 974 (1974).

2. Assan. R. Attali, J. R., Ballerio, G.. Girard, J. R.. e't al.: Some aspects of the physiology of glucagon. In: Diahetes, pp 144-179 W. J. Malaisse and J. Pirart: (Excerpta Medica, Amsterdam. 1974). 
3. Bryce. D., Yeh, M., Funderhurk. C .. Todd, H.. and Hertelendy, F.: Studic on growth hormone secretion. VII. Iffects of somatostatin on plasma (i. H., insulin, and glucagon in sheep. Diahetes, 24: 842 (1975).

4. Cahill, G. F., Jr., Zottu. S., and Farle, A. S.: In vivo effects of glucagon on hepatic glycogen phosphorylase and glucose-6-phosphatasc. Indocrinology 60: $265(1957)$

5. Char, V. (... and Creasy. R. K.: Lactate and pyruvate as fetal metabolic substrates, Pediat. Res., 10: 231 (1976)

6. Cherrington, A. D.. Chiasson, J. I... Liljencyuist, J. E.. Fennings, A. S. Keller, U., lacy, W. W.: The role of insulin and glucagen in the regulation of basal glueose production in the postabsorptive dog. J. ( lin. Invert.. 58 . $1 \$ 07(1976)$

7. Dobls, R., Sakurai, H., Sasaki, H., Fakona, (i., Valverde, I., Batetens, D). Orei, I... and Unger. R.: (iluciagen: Role in the hyperglycemia of diabetes mellitus. Science. $187: 544(1975)$

8. Exton, J. H.: (iluconeogenesis. Metabolism. 21: 945 (1972).

9. Felig. P.. Wahren. J.. Sherwin, R.. Hendler. R.: Insulin. glucagon and somatostatin in normal physiology and diathetes mellitus. Diabetes, 2.5 $1091(1476)$

10. Fiser, R. H., Jr.. Phelps, D. I... Williams, P. K. Sperling, M A. Fisher, D $A$ and (Oh, $W$.: Insulin-glucagon substrate interrelationships in the neonatal sheep. Amer. J. Obslet (iynecol., 120: $9.44(1974)$

11. Gerich. J. E... Iorenzi, M. Bier. D. M.. Schncider, V., Tsalikian, F., Karam, J. H.. and Forsham, P. H.: Prevention of human diahetic ketoatidosis by somatostatin. New lingl. J. Med.. 292: 985 (1975)

12. Gerich. J. E., Iorenzi, M.. Hane, S., Gustafson, G., Guillemin, R., and Forsham, P. H.: Fvidence for a physiologic role of pancreatic glucagon in human glucose homeostasis: Studies with somatostatin. Metabolism. 24 $175(1975)$.

13. Cierich, J. F.. L orenzi, M., Schneider, V., Iorsham, P. H. Iffect of somatostatin on plasmat glucose and insulin responses to glucagon and tolbutatmide in man. 3. ('lin. Endocrinol. Metab., 34: $1057(1974)$.

14. (jerich, J. F.. I.orenzi, M.. Schneider, V.. Karam, J. H. Rivier J Giullemin, R., and Forsham. P. H.: Lffects of somatostatin on plasmal glucose and glucagon levels in human diabetes mellitus. New Ingl. J. Med.. 201: 544 (1974)

15. Gerich. J. E.. Lorenzi, M. Schneider V. Kwan. ( W Karam J I: Guillemin. R.. and Forsham. P. H.: Inhibition of pancreatic glucagon response's to arginine by somattostatin in normal man and in insulin-dependent diabetics. Diatetes. 2.3: $876(1974)$

16. Cirard, J. R., Cuendet, (i. S.. Marliss, F. B., Kervran, A. Rieutort. M and Assan. R.: Fuels, hormones, and liver metabolism at term and during the carly postnatal period in the ratt. J. (lin. Invest. 52: $3190(147.3)$

17. Cirajwer, 1. A.. Sperling, M. A.. Sack, J. and Fisher. D. A.: Possible mechanisms and significance of the neonatal surge in glucigon secretion Studies in newborn lambs. Pediat. Res., 11:833 (1977)

18. James, F. J., Rayen. J. R.. Grasham. H. I., Makowski. H. I.. Meschia. (i. and Battaglia. F. ( . Fetal exygen consumption. carbon dioxide production, and glucose uptake in a chronic sheep preparation. Pediatrics. 50: 361 (1472)

Copyright \& 1977 Internationat Pediatric Research Foundation, Inc
19. Johnson, D. G.. Ensinck. J. W., Kixerker, D)., Palmer, J., and (inodner, ('. J.: Inhihition of glucagon and insulin secretion by somatostatin in the rat pancreas perfused in situ. Indecrinology, 96: 370 (1975)

20. Kuerker, D. J.. Ruch. W.. ('hideckel. E... Palmer. J.. Ciondner. ( . J. Fnsinck, I. and (jake, C. ('. Somatostatin: Hypothalamic inhibitor of the endecrinc pancreas. Science. 184: $482(1974)$

21. M(iarry, J. D.. Wright, P. H. and Foster. D. W. Hormonit control of ketogenesis. J. Clin. Invest. 55: $1202(1975)$.

22. Miller, 1. I .. Some direct actions of insulin, glucagon and hydrocortione on the isolated perfused rat liver. Recent Prog. Horm. Res., 17:5.39 (1961)

23. Morgan, ( . R., and I azarow. A.: Immunoassaly of insulin: Two antibudy system. Plasma insulin levels of normal. subdiabetic and diabetic rats. Diabeles. 12: $115(196.3)$

24. Parilla, R.. Goodman, M. N. and Toewe, ( . J.: fiffect of glacagon: Insulin ratios on hepatic metabolism. Diabetes. 23: $725(1974)$

25. Samols. F., Marri. (i.. and Marks, V.: Promotion of insulin secretion by glucagon. Lancet ii: $415(1965)$

26. Sherwin. R. S. Fisher, M., Hender, R. and Felig. P: Hypergluciagonemia and blood glucose regulation in normal obese and diabetic subjects. New Engl. J. Med. 294: $455(1976)$

27. Sperling. M. A. Del amater, P. V.. Finer. R. H.. Fisher. D. A. and Kazenelson. M.: Development and applicition of a radioimmunoassily for glucagon. (Cin. (hem.. 20):566 (1974).

28. Sperling. M. A. Delamater, P. V. Phetes, D. Fiser R H Oh W and Fisher. D. A.: Spontaneous and amino acid stimulated glucagon secretion in the immediate pest-natal period; relation to glucose and insulin. J. Clin. Invest. 5.3: $1159(1974)$

29. Tsouks, N. (i.. Colwill, J. R., Battiglia, F. C.. Makouski, E. I and Meschia, ( $i$ : ('omparison of glucose, fructose and ()., uptakes by fetuses of fed and starved ewer. Amer. J. Physiol., 221:234 (1472).

30. Unger, R. H.: Alpha- and Beta-cell interrelationships in health and discase. Metabolism. 23: $581(1974)$

31. Vale, W. Brizcata, P.. Rivier, ( .. Brown, M., Boss, B.. Rivier, J.. Burgus, R.. I.ing, N. and Guillemin. R.: Somitestatin. Recent Prog. Horm. Res. 31: $36.5(1975)$.

32. Wahren, J.. and Felig, P.: Influence of somatostatin on carbohydrate disposal and absorption in diathetes mellitus. I ancet, ii: 1213 (1976)

33. Dr. Sperling is a recipient of a Rescarch (areer Development Award from the United States Public Health Service (I KO + HD) (0)(1)2(y)

34. This research was supported in part by United States Public Health Sorvice (irant HD) 07087 , and HD) 04270 from the National Institute of child Health and Disease. National Institutes of Health. Bethesda. Maryland. The Juvenile Diabetes Foundation. and Americatn Diabetes Association. Southern Califurnia.

35. Reyuests for reprints should be addressed to: M. A. Sperling. M.D. Pediatric

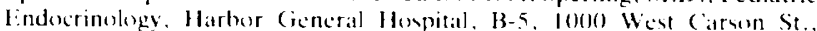
Torrance. (alif. 90509 (USA)

36. Received for publication September 13, 1976.

37. Accepted for publication February 15, 1977.
Broathing

continuous positive airway pressure hyperventilation vagal control

\section{Lack of Effects of Continuous Positive Airway Pressure on Vagal Control of Breathing in Term and Preterm Newborn Lambs}

PII:RRI: J. MONIN, WILIIAM J. (ASHORI: DAVID O. HAKANSON. ANI) WILILAM (OH'W:

Department of Pediatrics. Women and Infants Hospital of Rhode Island and Section of Human Reproductive and Developmental Medicine, Brown University Program in Medicine, Providence, Rhode Island, USA

\section{Summary}

The relationships between tidal volume $\left(V_{1}\right)$, ventilation $\left(\dot{V}_{1}\right)$, inspiratory duration (Ti), and total breath duration $\left(\mathbf{T}_{t+1}\right)$ during hyperventilation induced by $4 \% \mathrm{CO}_{2}$ exposure were studied in five term and four preterm lambs to evaluate the effect of continuous positive airway pressure (CPAP) on control of breathing. At barometric pressure $V_{\text {, }}$ was $308 \pm 44 \mathrm{ml} / \mathrm{kg}$ and $V_{\text {, was }} 41.5 \pm 10.3 \mathrm{ml}$ (mean $\left.\pm S D\right)$ in term lambs; in preterm animals, $\dot{V}_{\text {, }}$ was $511 \pm 133 \mathrm{ml} / \mathrm{kg}$ and $V_{\text {, }}$ was $32.6 \pm 0.6 \mathrm{ml}$. Application of CPAP $\left(+5 \mathrm{~cm} \mathrm{H}_{2} \mathrm{O}\right)$ produced an increase in thoracic gas volume of $9.6 \pm 3.4 \mathrm{ml} / \mathrm{kg}$ in term lambs and $9.6 \pm$ $3.5 \mathrm{ml} / \mathrm{kg}$ in preterm lambs. $\dot{V}_{1}, V_{1}$, and the slope of the $\dot{V}_{1}-V_{1}$ relationship were not significantly affected by CPAP. At baro- 